\title{
SISTEM KONTROL DAN KINERJA: PENDEKATAN INTERAKSI DAN SISTEM UNTUK RISET KONTINJENSI DALAM AKUNTANSI MANAJEMEN
}

\author{
Oleh \\ Irma Ibrahim, S.E.,MM
}

\begin{abstract}
The research was done to investigate the influence of control systems on firms' performance, which involved perceived environment uncertainty (PEU). Using interaction and system approach, which use to test of fit between contextual and organizational variables, tested the hypothesis. Therefore, this research has theoretical and methodological meanings.
\end{abstract}

The data was collected from managers of Bank Perkreditan Rakyat (BPR), where the Branch of Indonesian Central Bank at Makassar has supervised them. There are 97 samples was collected by using mail survey and was chosen by purposive random sampling. The variables include $P E U$, control systems and financial performances. According to early literature, the control systems were categorized into operational control systems, management control systems and strategic planning, while financial performance was measured by ROA.

The result indicates that control systems affected to financial performance, which involved PEU and using system approach. Any way, based on this research, the system approach is better than interaction approach.

Key Word: Control Systems, Perceived Environment Uncertainty, Interaction Approach, System Approach, Fit, Performance.

\section{PENDAHULUAN}

Sistem kontrol merupakan bidang penting dalam perusahaan. Sistem kontrol didefinisikan sebagai semua prosedur dan sistem formal yang menggunakan informasi untuk menjaga atau mengubah pola aktivitas organisasi (Simons, 1987). Sistem kontrol berkaitan dengan strategi pencapaian tujuan yang diukur dari kinerja organisasional (Anthony and Vijay G., 1998).

Riset-riset terdahulu menunjukkan bahwa penerapan sistem kontrol organisasi secara efektif akan memberi dampak yang signifikan terhadap peningkatan kinerja. Namun, hubungan tersebut tidak secara langsung demikian, tetapi terdapat faktor kontekstual (misalnya ketidakpastian lingkungan (perceived environtmental uncertainty $(P E U))$ yang ada dalam hubungan antara sistem kontrol dengan kinerja organisasi tersebut (Chong VK, 1996). Argumentasi yang mendukung proposisi 
tersebut adalah adanya kenyataan bahwa lingkungan merupakan faktor kontekstual penting yang mempunyai dampak kuat terhadap kinerja perusahaan. Lebih jauh, dalam terminologi kontinjensi dinyatakan bahwa efektivitas organisasi merupakan fungsi dari fit (kesesuaian) antara struktur organisasi dan lingkungan dimana organisasi tersebut beroperasi (Duncan dan Ken Moores, 1989).

Riset-riset yang menguji hubungan antara sistem kontrol dengan kinerja organisasi yang melibatkan variabel kontekstual telah diakui oleh kalangan peneliti sebagai aplikasi teori kontinjensi. Pendekatan kontinjensi merupakan sebuah aplikasi konsep teori yang menyatakan bahwa tidak ada suatu sistem kontrol terbaik yang dapat diterapkan untuk semua organisasi dan penerapan sistem kontrol secara tepat harus memandang adanya keterlibatan variabel kontekstual dimana organisasi tersebut berada.

Kajian yang dilakukan oleh Otley (1980) terhadap hasil-hasil riset Gordon dan Miller (1976), Dermer (1977), Watherhouse dan Tiessen (1978), Burn dan Waterhouse (1975) serta Hayes (1977) dan Piper (1977) menunjukkan bahwa riset-riset tersebut sangat sedikit sekali menggunakan literatur-litaratur teori organisasi dan bahkan terdapat beberapa penyimpangan terhadap literatur-literatur organisasi. Penyimpangan tersebut berkatan dengan desain framework kontinjensi, terutama pada aspek metode pengujian.

Lebih jauh, Fulmer dan Rue (1974), Kenis (1979), Boulton (1982), Simons (1987), Mak (1989), Moers dan Hartmann (1999), Shield et al, (2000) Chong VK et al (2001), Chong VK dan Chong KM (2004) menunjukkan pentingnya keterlibatan variabel kontekstual dalam hubungan antara sistem kontrol dengan kinerja organisasi. Pendekatan kontinjensi merupakan terobosan penting yang mampu menggeser pendekatan universalistik (Bays, 2000; Duncan dan Keith, 1989; dan Drazin dan Van de Ven, 1985).

Malasahnya, riset-riset empirik terdahulu di bidang kontinjensi menunjukkan adanya karakteristik pengujian (testing) hubungan antara variabel-variabel dalam model kontinjensi yang sederhana dan tidak terpola (Fry dan Smith dalam Duncan dan Ken Moores, 1989). Kesesuaian antara variabel kontinjensi dengan variabel organisasional dalam riset-riset tersebut dibangun dalam proposisi hubungan yang berbeda-beda, meskipun, konsep sentral dari proposisi kontinjensi adalah fit, yang merupakan kesesuaian antara variabel kontekstual dengan desain organisasional. Dalam hal ini, Drazin dan Van de Ven (1985) kemudian melaporkan adanya pendekatan konseptual mengenai fit. Menurut mereka, setidaknya ada tiga pendekatan yang berbeda dalam pengukuran fit antara variabel organisasional dan variabel kontinjensi. Ketiga pendekatan tersebut adalah pendekatan seleksi, pendekatan interaksi dan pendekatan sistem.

Pendekatan seleksi mengasumsikan fit sebagai kesesuaian (congruence) antara variabel kontekstual dengan struktur organisasi, misalnya formalisasi dan 
sentralisasi. Namun pendekatan ini tidak secara jelas menguji pengaruh hubungan antara variabel kontekstual dengan organisasional terhadap kinerja. Pendekatan interaksi, mengasumsikan konsep fit sebagai interaksi bivariate. Fit merupakan interaksi variabel-variabel kontekstual-organisasional yang dapat memberi dampak terhadap kinerja. Dalam perkembangannya, pendekatan interaksi banyak diaplikasi oleh para peneliti dengan menggunakan dua konsep analisis, multiple interaction dan resydual analysis. Namun demikian, terdapat perbedaan pandangan yang tajam mengenai validitas penggunaan kedua konsep di atas. Perbedaan hasil riset antara Dewar dan Werbel (1979), Duncan dan Moores (1989), Hartmann dan Frank Moers (1999), Mak (1989), Bambang Riyanto (2001) dan Muhammad Ja'far S. (2001) cukup menjadi bukti mengenai hal ini.

Pendekatan ketiga dalam uji fit adalah pendekatan sistem, yang mengasumsikan fit sebagai konsistensi dari berbagai variabel kontinjensi dan variabel organisasional yang memberi dampak terhadap kinerja. Dengan kata lain, pendekatan sistem merupakan pendekatan yang mengaplikasikan hubungan variabel kontekstual-organisasional secara simultan dalam suatu sistem yang dapat berimplikasi pada peningkatan kinerja. Namun sejauh ini, masih sedikit sekali penelitian yang menggunakan pendekatan ini.

Mendasarkan pada uraian di atas, penelitian ini secara khusus mengevaluasi penggunaan berbagai pendekatan uji dalam riset-riset kontinjensi. Pendekatan yang hendak diuji meliputi penggunaan konsep multiple regression dan residual analysis dalam pendekatan interaksi, dan penggunaan konsep distance dalam pendekatan sistem. Penelitian ini tidak memandang pendekatan seleksi sebagai alternatif uji mengingat ketidakjelasan pendekatan ini dalam riset kontinjensi, sebagaimana telah dijelaskan sebelumnya.

Secara teoritis, penelitian ini hendak menguji pengaruh hubungan variabel kontekstual (PEU) dengan variabel organisasional (sistem kontrol) terhadap kinerja keuangan organisasi. Sejalan dengan gagasan Anthony (dalam Mak, 1989) dan pandangan Veliyath, et al (1997), sistem kontrol sebagai variabel organisasional dibagi dalam tiga level, yaitu operational control system (OCS), management control system (MCS) dan strategic planning (SP).

\section{RUMUSAN MASALAH DAN TUJUAN PENELITIAN}

Sejauh ini, kritikan terhadap riset kontinjensi lebih banyak diarahkan dalam desain framework kontinjensi, terutama pada aspek metode pengujian. Drazin dan Van de Ven (1985) mengajukan tiga pendekatan pentig dalam riset kontinjensi, meliputi: seleksi, interaksi dan sistem. Kenyataan bahwa dalam pendekatan seleksi dan interaksi memunculkan sejumlah kelemahan baik dalam konsep maupun konsekwensi hasil, arah metode pendekatan kemudian difokuskan terhadap pendekatan sistem.

Mengacu pada fakta empirik dan latar belakang penelitian yang telah disebutkan di atas, masalah dalam penelitian ini dapat dirumuskan sebagai berikut: 
Diantara pendekatan interaksi dan sistem dalam uji fit, diprediksikan terdapat satu pendekatan terbaik dari sudut pandang metodologis dan teoritis.

Secara teoritis, perlu diuji pengaruh hubungan multidimensional antara variabel OCS, MCS dan SP dengan variabel PEU, terhadap kinerja perusahaan.

Lebih jauh, berdasarkan latar belakang serta rumusan masalah yang telah dikemukakan, secara garis besar penelitian ini memiliki dua tujuan utama:

Tujuan metodologis. Dari aspek metodologi penelitian, penelitian ini hendak menguji dan mengevaluasi penggunaan pendekatan uji fit dalam riset-riset kontinjensi. Sesuai dengan kerangka konsep yang diajukan oleh Drazin dan Van de Ven (1985), pendekatan uji fit yang hendak dianalisis meliputi konsep multiple regression dan resydual analysis dalam pendekatan interaksi, dan konsep distance dalam pendekatan sistem.

Tujuan teoritis. Dari aspek teoritis mengenai konsep kontinjensi, penelitian ini hendak menguji hubungan antara variabel kontekstual dengan variabel organisasional dan implikasinya terhadap kinerja keuangan organisasi.

\section{TELAAH PUSTAKA DAN PENELITIAN TERDAHULU}

\section{Perspektif Kontinjensi}

Sistem kontrol didefiniskan sebagai semua prosedur dan sistem formal yang menggunakan informasi untuk menjaga atau mengubah pola aktivitas perusahaan (Simons, 1987). Dalam studi-studi yang ada, sistem kontrol dinyatakan dapat mempengaruhi pencapaian kinerja dengan melibatkan variabel kontinjensi, seperti PEU. Lebih jauh, Otley (1980) memandang pentingnya perspektif kontinjensi dalam riset-riset akuntansi. Otley (1980) menunjukkan adanya dampak penggunaan

pendekatan kontinjensi dalam menjelaskan hasil-hasil riset sistem kontrol yang berbeda-beda.

Pada awal perkembangan teori kontinjensi, framework kontinjensi dipandang sebagai model linier hubungan antara desain struktur organisasi dengan sistem kontrol organisasi. Model ini dikritisi oleh Otley (1980) dengan mengemukakan gagasan framework kontinjensi minimal (minimum necesary contigency framework). Pada model yang diperkenalkan Otley ini, sistem kontrol tidak dipandang sebagai konsekwensi logis dari kebijakan desain struktur organisasi, melainkan sebagai bagian integral dari paket pengendalian organisasi dan sejajar dengan desain struktur organisasi yang diterapkan.

Pendekatan Multiple Interaction

Terdapat tiga pendekatan dalam kosep fit sebagaimana dikemukakan oleh Drazin dan Van de Ven (1985), yang meliputi seleksi, interaksi dan sistem. Tabel 1 pada lampiran 2 menunjukkan ketiga konsep fit yang diajukan oleh Drazin dan Van de Ven (1985). 
Pendekatan seleksi menghubungkan antara variabel kontekstual dengan variabel organisasional, namun tidak secara jelas mengkorelasikan hubungan kedua variabel tersebut dengan kinerja organisasi. Pendekatan multiple interaction memandang bahwa pengaruh fit antara variabel kontekstual dengan variabel organisasional diekspresikan dengan bentuk perkalian antara variabel kontekstual dengan variabel organisasional dalam model regresi. Koefisien signifikansi dari order tertinggi dari interaksi dalam persamaan regresi menunjukkan adanya dukungan terhadap hipotesis yang dikembangkan. Dalam persepektif ini, misalkan Xc mewakili variabel kontekstual dan Xo mewakili variabel organisasional maka persamaan regresi dapat dituliskan

sebagai berikut:

$\mathrm{Y}=\mathrm{a}+\mathrm{b} 1 \mathrm{Xc}+\mathrm{b} 2 \mathrm{Xo}+\mathrm{b} 3 \mathrm{XcXo}$

Dimana,

$\mathrm{Y} \quad$ : Kinerja (organisaional atau manajeral)

a : konstanta

b1,2 : koefisien regresi Xc dan Xo dan koefesien interaksi XcXo

Xc, Xo : variabel kontinjensi dan variabel organisasional.

XcXo : Order kedua interaksi Xc dan Xo.

Bila dalam model terdapat $\mathrm{i}$ variabel kontekstual dan $\mathrm{j}$ variabel organisasional, maka order tertinggi dalam persamaan regresi tersebut adalah $(i+j)$.

Sebagaimana ditunjukkan dalam persamaan (1) di atas, untuk data dengan skala ordinal (sebagian peneliti menyatakan minimal skala interval), maka koefesien yang dapat diinterpretasikan adalah b3 (Duncan dan Ken Moores (1989), Gul dan Chia (1994)). Hal ini karena pada skala ordinal dan interval tidak ada nilai 0 (zero), yang dengan demikian data dapat diskala ulang (rescaled).

Perlakuan skala ulang tersebut akan merubah nilai koefesien regresi kecuali parameter b3 dalam persamaan (1). Proses ini dapat ditunjukkan sebagai berikut: misalkan nilai Xc pada persamaan (1) ditambah dengan nilai konstanta tertentu (rescaled) misalnya $\mathrm{Q}$, dan asumsikan hasil rescaled tadi adalah $\mathrm{Zc}$, maka $\mathrm{Zc}=\mathrm{Xc}+$ $\mathrm{Q}$, dan $\mathrm{Xc}=\mathrm{Zc}-\mathrm{Q}$. Dengan demikian: 
$\mathrm{Y}=\mathrm{a}+\mathrm{b} 1 \mathrm{Xc}+\mathrm{b} 2 \mathrm{Xo}+\mathrm{b} 3 \mathrm{XcXo}$

$\mathrm{Y}=\mathrm{a}+\mathrm{b} 1(\mathrm{Zc}-\mathrm{Q})+\mathrm{b} 2 \mathrm{Xo}+\mathrm{b} 3(\mathrm{Zc}-\mathrm{Q}) \mathrm{X} 0$

$\mathrm{Y}=\mathrm{a}-\mathrm{b} 1 \mathrm{Q}+\mathrm{b} 1 \mathrm{Zc}+(\mathrm{b} 2-\mathrm{b} 3) \mathrm{Xo}+\mathrm{b} 3 \mathrm{ZcXo}$

Bila $a-b 1 Q=a^{\prime}$ dan $b 2-b 3=b^{\prime}$ maka persamaan (2) dapat diubah menjadi

$\mathrm{Y}=\mathrm{a}^{\prime}+\mathrm{b} 2^{\prime}+\mathrm{b} 3 \mathrm{ZcXo}$

Tampak bahwa persamaan (3) merubah nilai b2 menjadi b2' sementara b3, sebagai term koefesien interaksi, tetap dan tidak berubah. Dengan demikian hanya b3 saja memiliki arti (meaningfull).

Pendekatan Residual Analysis

Pendekatan residual analysis mengacu pada konsep nilai residual dari persamaan regresi. Dalam pendekatan ini, residual diasumsikan sebagai unfit dari persamaan regresi. Terdapat tiga tahap dalam uji ini. Tahap pertama adalah penentuan desain hubungan variabel organisasional dengan kontekstual. Dalam hal ini, sistem kontrol didesain sebagai variabel dependen dan PEU sebagai variabel indepeden. Oleh karena itu persamaan dapat dibentuk sebagaimana dinyatakan dalam persamaan (4).

$\mathrm{Yi}=\mathrm{a}+\mathrm{b}(\mathrm{X})+\varepsilon \mathrm{i}$

Dimana,

$\mathrm{Yi} \quad=$ sistem kontrol ke $\mathrm{i}$

$\mathrm{a}, \mathrm{b}=$ konstanta dan koefesien regresi

$\mathrm{X} \quad=\mathrm{PEU}$

\&i $\quad=$ residual ke $\mathrm{i}$

Jika hubungan antara Yi dan X merupakan fit kedua variabel, maka ei merupakan unfit dari model regresi kedua variabel tersebut. Oleh karena itu, jika \&i dihubungkan dengan variabel kinerja maka nilai unfit tersebut akan berpengaruh negatif terhadap kinerja.

Tahap kedua dari persamaan tersebut adalah menentukan nilai absolut dari residual dan menghubungkan nilai absolut tersebut dengan kinerja. Dalam hal ini nilai absolut residual (unfit) dinyatakan sebagai variabel independen dan kinerja dinyatakan sebagai variabel dependent. Penggunaan notasi absolut dikarenakan unfit merupakan besaran konsep dan oleh karena itu tanda (positif atau negatif) bukan persoalan yang relevan (Duncan dan Ken Moores, 1989). Berdasarkan operasionalisasi variabel tersebut, persamaan kedua dapat dinyatakan sebagai berikut: 
$\mathrm{Y}=\mathrm{a}-\mathrm{bi}|\varepsilon \mathrm{i}|+\varepsilon$

Y : kinerja

a, bi : konstanta, koefesien ke i dari $\mid$ ci $\mid$

$\mid$ ci $\mid$ : nilai absolut residual ke i dari persamaan (4)

$\varepsilon$ : $\quad$ random error (residual dari persamaan (5)).

Pendekatan Sistem: konsep Distance

Pendekatan seleksi dan interaksi dalam fit memfokuskan pada bagaimana faktor tunggal dari variabel kontekstual berpengaruh terhadap faktor-faktor organisasional dan bagaimana pasangan variabel kontekstual-organisasional tersebut berinteraksi dalam mempengaruhi kinerja. Oleh kalangan reductionism, cara ini dipandang sebagai dekomposisi dari variabel-variabel organisasional dan kontekstual yang secara efektif dapat menjelaskan hubungan keseluruhan organisasi.

Pandangan kalangan reductionism tersebut ditentang oleh Miller (1981) dan Drazin dan Van de Ven (1985) dengan menyatakan bahwa pemahaman hubungan variabel kontekstual-organisasional hanya dapat dilihat secara simultan dalam aspekaspek kontinjensi dan alternatif struktural (organisasional) serta kriteria kinerja yang secara holistik dapat digunakan untuk memahami desain organisasi. Oleh karena itu model tersebut harus sistemik, yang dikenal sebagai pendekatan sistem.

Pendekatan sistem menekankan pada adopsi multivariate untuk menguji pola konsistensi diantara dimensi organisasional, kontekstual dan kinerja. Hubungan multidimensional variabel kontekstual dan organisasional harus konsisten dalam seperangkat sistem guna menunjang pencapaian kinerja. Jika model tersebut digambarkan dalam dua dimensi variabel, akan tampak seperti pada gambar 1 (Lampiran1).

Terdapat tiga langkah dalam uji fit dengan pendekatan sistem. Pertama, pengembangan tipe ideal dari variabel kontekstual dan organisasional. Tipe ideal merupakan semua bentuk kombinasi ideal yang mungkin antara variabel kontekstual dengan variabel organisasional dalam kerangka mencapai kinerja yang tinggi. Berdasar pada gambar 4, semakin dekat jarak perusahaan dengan tipe ideal maka semakin tinggi kinerjanya. Dengan kata lain, semakin jauh jarak (deviasi) perusahaan dengan tipe ideal maka semakin kecil kinerja yang dapat dicapai.

Tahap kedua adalah menghitung nilai distance dari skor unfit tersebut dengan menggunakan pengukuran Euclidean distance (Drazin dan Van de Ven, 1985). Skor unfit merupakan jumlah dari deviasi setiap skor variabel kontekstual dan organisasional dari skor tipe ideal. Rumus yang digunakan untuk menghitung distance tersebut seperti ditunjukkan dalam persamaan (6). Tahap ketiga pada pendekatan 
sistem adalah mengkorelasikan atau meregreskan nilai distance yang diperoleh dengan variabel kinerja.

DISTij $=\sqrt{ }\left(\sum(\mathrm{Xis}-\mathrm{Xjs})^{2}\right.$

Dimana,

DISTij $=$ Euclidean distance dari titik skor ke $\mathrm{j}$ ke titikideal $\mathrm{i}$

Xis $=$ skor dari tipe ideal pada dimensi ke s dari variabel kontekstual atau organisasional.

$\mathrm{Xij}=$ skor riil $\mathrm{ke} \mathrm{j}$ pada dimensi ke $\mathrm{s}$ dari variabel kontekstual atau organisasional.

(Drazin dan Van de Ven, 1985; NIST, 2004)

Ketidakpastian Lingkungan Yang Dipersepsikan, Sistem Kontrol dan Kinerja Keuangan. PEU didefiniskan sebagai kondisi lingkungan eksternal yang dapat mempengaruhi operasional perusahaan (Otley, 1980). Dalam penelitiannya, Burns dan Stalker (dalam Gudono, 1999) mengidentifikasi tipe struktur dan praktik manajemen yang tepat untuk berbagai kondisi lingkungan yang berbeda.

Ketidakpastian merupakan rasa ketidakmampuan individu dalam memprediksi sesuatu secara tepat (Gudono, 1999) dan persepsi ketidakpastian lingkungan (PEU) didefinisikan sebagai persepsi individual atas ketidakpastian yang berasal dari lingkungan (Gregson et al, 1994). Pada dasarnya, PEU merupakan ketidakmampuan persepsi manajemen top dalam memprediksi lingkungan eksternal organisasi secara tepat (Milliken, 1987). Gul dan Chia (1994) menyimpulkan bahwa PEU lebih merupakan persepsi manajemen terhadap envirotmental uncertainty daripada environtmental uncertainty itu sendiri.

Riset-riset akuntansi manajemen telah banyak mengaplikasi teori kontinjensi dalam studi tentang desain sistem informasi manajemen dan kinerja (Chenall dan Moris, 1986; Gul, 1991). Secara khusus, studi-studi tersebut memfokuskan pada hubungan antara aspek-aspek variabel kontekstual (seperti PEU), karakteristik sistem informasi manajemen dan kinerja. Sistim informasi manajemen dalam hal ini dipandang sebagai subsistem kontrol yang berpengaruh terhadap kinerja. Dengan konsep teori kontinjensi, fit antara PEU yang tinggi dan cakupan sistem informasi yang luas akan berpengaruh terhadap kinerja dibanding fit antara sistem informasi yang luas dengan PEU yang rendah (misfit) (Gordon dan Narayanan, 1984). Hal demikian 
merupakan pandangan teori kontinjensi yang manyatakan bahwa kapasitas informasi atau sistem kontrol (seperti OCS, MCS dan SP) harus sesuai dengan kondisi ketidakpastian yang dihadapi perusahaan (Gerloff dalam Gul dan Chia, 1994). Melalui penyesuaian kapasitas dengan lingkungan, organisasi akan mampu meningkatkan kinerja. Dengan kata lain, jika ketidakpastian lingkungan meningkat, maka tingkat keluasan penggunaan sistem kontrol juga diharapkan meningkat untuk mendorong pencapaian kinerja yang tinggi.

Sejauh ini, dinyatakan bahwa fit antara sistem kontrol dengan PEU dapat meningkatkan kinerja perusahaan (Merchant, 1981; Gul dan Chia, 1994; Gul, 1991; Chenall dan Moris, 1986; Gordon dan Narayanan, 1984; Gerloff dalam Gul dan Chia, 1994). Namun, riset-riset yang dilakukan selama ini kurang memandang pada aspek keterlibatan variabel sistem kontrol secara luas, misalnya penggunaan sistem kontrol pada level operasional (OCS), manajerial (MCS) dan perencanaan strategi (SP).

OCS sendiri merupakan subsistem kontrol akuntansi pada tataran operasional. Pada level ini, aktivitas yang terpgrogram digunakan dan diaplikasikan secara sempit. OCS lebih cocok diterapkan pada pola aktivitas yang menunjukkan hubungan input-output, dan judgment memegang peranan yang relatif kecil (Veliyath, etal, 1997).

Pada sisi lain, MCS dimaksudkan sebagai kontrol terhadap penemuan dan penggunaan sumber-sumber pencapaian tujuan perusahaan secara efektif. MCS menekankan pada program dan pusat pertanggungjawaban serta berkaitan dengan aktivitas dimana hubungan input-output sulit ditentukan. MCS merupakan integrasi, koordinasi dan memiliki banyak aplikasi dibanding OCS. Aplikasi judgment managerial lebih banyak digunakan pada level ini.

Sementara itu, perencanaan strategi (strategic planning) memfokuskan pada tujuan, perubahan tujuan, sumber-sumber untuk mencapai tujuan serta kebijakan usaha dan pemerintah yang berlaku. SP diformulasikan dalam jangka panjang berkaitan dengan strategi. Esensi dasar dari SP adalah monitoring dan pencapaian informasi yang berkaitan dengan lingkungan eksternal (Veliyath, et al, 1997).

\section{KERANGKA PEMIKIRAN TEORITIS DAN HIPOTESIS}

Riset yang sekarang ini dilakukan bermaksud mengevaluasi konsep fit baik secara metodologis maupun teoritis. Aspek motodologis berkaitan dengan penggunaan metode multiple interaction, residual analysis dan pendekatan sistem. Sementara itu, aspek teoritis berkaitan dengan pengembangan variabel organisasional dengan mengaplikasikan variabel OCS, MCS dan SP dalam dasain sistem kontrol.

Berdasarkan tinjauan teori yang telah dikemukakan, kerangka pemikiran teoritis dapat dikembangkan sebagaimana dinyatakan dalam gambar 2 (Lampiran 1). 
Atas dasar kerangka pemikiran teoritis tersebut hipotesis penelitian dapat diturunkan sebagai berikut:

Hipotesis 1; PEU memoderasi pengaruh OCS, MCS dan SP terhadap kinerja perusahaan.

Hipotesis 2; Deviasi fit dari OCS, MCS dan SP terhadap PEU berpengaruh negatif terhadap kinerja perusahaan.

Hipotesis 3; Distance dari PEU, OCS, MCS dan SP dalam sistem dimensi kontekstual- organisasional berpengaruh negatif terhadap kinerja perusahaan

\section{METODE PENELITIAN}

\section{Populasi dan Sampel}

Populasi dalam penelitian adalah CEO atau setingkat manajer Bank Perkreditan Rakyat (BPR) se Sul-sel yang terdaftar dalam wilayah kantor cabang (KC) Bank Indonesia (BI) di Makassar. Pemilihan BPR sebagai obyek penelitian disebabkan kemampuan mereka bertahan pada kondisi krisis yang dimulai sejak awal tahun 1997 (Joko Sugiarsono, 1999).

Diantara kantor cabang BI yang ada (3 KC BI di Sulse-sel), KC BI Makassar membawahi 64\% BPR di seluruh Sul-sel, yang dengan demikian diharapkan mampu memenuhi representasi sampel yang diambil. Di sisi lain, faktor confounding effect juga menjadi pertimbangan dalam desain sampel.

Sampel diambil dengan teknik purposive random sampling, dengan kriteria sampel BPR sehat berdasarkan nilai ROA sebesar 1,215\% (BI Makassar, 2000). Cara pengumpulan sampel dilakukan dengan mail survey terhadap 160 responden yang ditetapkan dalam sampel. Jumlah sampel yang kembali sebanyak 102 sampel dengan respon rate $63,75 \% .5$ dari 102 sampel yang kembali didrop karena tidak memenuhi kriteria, yang berarti terdapat 97 sampel yang dianalisis dalam penelitian ini.

\section{Definisi Operasional Variabel}

Variabel dalam penelitian ini meliputi tiga variabel utama, yaitu variabel kontekstual yang berupa PEU dan organisasional yang terdiri dari OCS, MCS, dan SP, serta variabel outcome yang berupa kinerja keuangan (ROA). Tabel 2 pada lampiran 2 mendeskripsikan definisi operasional masing-masing variabel.

Teknik Analysis

Pendekatan multiple interaction untuk uji hipotesis 1, mengacu pada persamaan (1). Dalam hal ini, secara komprehensif desain uji statistiknya adalah sebagai berikut:

$$
\begin{aligned}
\mathrm{Y}= & \mathrm{a}+\mathrm{b} 1 \mathrm{X} 1+\mathrm{b} 2 \mathrm{X} 2+\mathrm{b} 3 \mathrm{X} 3+\mathrm{b} 4 \mathrm{X} 4+\mathrm{b} 5 \mathrm{X} 1 \mathrm{X} 2+\mathrm{b} 6 \mathrm{X} 1 \mathrm{X} 3+ \\
& \mathrm{b} 7 \mathrm{X} 1 \mathrm{X} 4+\ldots \ldots \ldots \ldots+\mathrm{b} 1 \mathrm{X} 1 \mathrm{X} 2 \mathrm{X} 3+\mathrm{b} 12 \mathrm{X} 1 \mathrm{X} 2 \mathrm{X} 4+\ldots \ldots \ldots \\
& +\mathrm{b} 15(\mathrm{X} 1 \mathrm{X} 2 \mathrm{X} 3 \mathrm{X} 4)
\end{aligned}
$$


Dimana,

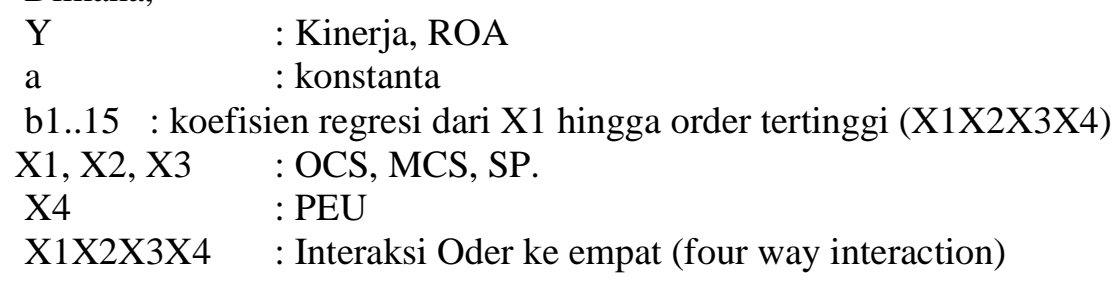

Pendekatan residual analysis untuk uji hipotesis 2, mengacu pada persamaan (4) dan (5). Dalam hal ini secara komprehensif desain uji statistiknya adalah sebagai berikut: Tahap 1.

$\mathrm{Yi}=\mathrm{a}+\mathrm{b}(\mathrm{X})+\varepsilon \mathrm{i}$

Dimana,

$\mathrm{Yi} \quad=$ sistem kontrol ke i (OCS, MCS, SP)

$\mathrm{a}, \mathrm{b}=$ konstanta dan koefesien regresi

$\mathrm{X} \quad=\mathrm{PEU}$

ci $\quad=$ residual ke dari regresi sistem kontrol ke i terhadap PEU.

Tahap 2

$$
\begin{aligned}
& \mathrm{Y}=\mathrm{a}-\mathrm{b} 1|\varepsilon 1|-\mathrm{b} 2|\varepsilon 2|-\mathrm{b} 3|\varepsilon 3|+\varepsilon^{\prime} \\
& \mathrm{Y} \quad \text { : kinerja } \\
& \text { a, bi : konstanta, koefesien ke i dari } \mid \text { ci } \mid \\
& |\varepsilon 1 . .3| \quad \text { : nilai absolut residual OCS-PEU, MCS-PEU dan } \\
& \text { SP-PEU } \\
& \text { ع' } \quad \text { : random error (residual dari persamaan (8)). }
\end{aligned}
$$

\begin{tabular}{|c|c|}
\hline \\
\hline $\begin{array}{l}\text { DISTij }=\sqrt{ }\left(\sum(\mathrm{Xis}-\mathrm{Xjs})^{2}\right. \\
\text { Dimana, } \\
\text { DISTij } \quad=\text { Euclidean distance dari titik skor }(\mathrm{j}) \text { ke titik ideal i }\end{array}$ & $\begin{array}{l}\text { DISTij }=\sqrt{ }\left(\sum(\mathrm{Xis}-\mathrm{Xjs})^{2} \ldots \ldots \ldots \ldots \ldots \ldots \ldots \ldots \ldots \ldots \ldots \ldots \ldots \ldots \ldots \ldots \ldots\right. \\
\text { Dimana, }\end{array}$ \\
\hline \multicolumn{2}{|r|}{$\begin{array}{l}=\text { skor dari tipe ideal pada dimensi ke (s) dari } \\
\text { variabel kontekstual atau organisasional. }\end{array}$} \\
\hline & si ke (s) dari variabel \\
\hline
\end{tabular}

Konsep distance dari pendekatan system untuk uji hipotesis 3, mengacu pada persamaan (6). Dalam hal ini secara komprehensif desain uji statistiknya adalah sebagai berikut:

(Drazin dan Van de Ven, 1985; NIST, 2004) 


\section{HASIL PENELITIAN}

Statistik Deskriptif, Validitas, dan reliabilitas Statistik deskriptif, validitas dan reliabilitas instrumen variabel yang digunakan untuk memperoleh data disajikan dalam Tabel 3 (Lampiran 2). Berdasarkan pada tabel 3 tersebut, dapat dijelaskan bahwa untuk data primer (PEU, OCS, MCS, SP) rata-rata item berada pada level di atas 4. Hal ini berarti responden mempersepsikan faktor kontekstual sebagai faktor yang memiliki ketidakpastian menengah-tinggi (medium-high), dan rata-rata responden mengaplikasikan sistem kontrol secara canggih (sophisticate). Nilai $|\mathrm{Z}|<1,96$ menunjukkan bahwa data normal untuk semua variabel. Semua alat ukur juga valid dan reliabel di atas 0.6 (Nunally, dalam Ghozali, 2002).

\section{Uji Hipotesis 1}

Hipotesis 1 dalam penelitian ini diuji dengan model multiple interaction untuk menunjukkan moderasi variabel PEU terhadap pengaruh variabel OCS, MCS dan SP terhadap kinerja keuangan (ROA). Berdasar aplikasi persamaan (7) dapat dinyatakan bahwa hipotesis 1 ditolak dengan merujuk hasil uji yang disajikan pada tabel 4 (Lampiran 2). Nilai p-value untuk $\beta_{15}$ adalah 0.167 dengan nilai $t=1.394$.

Dengan demikian, dapat disimpulkan bahwa dengan pendekatan multiple interaction, PEU tidak memoderasi pengaruh OCS, MCS dan SP terhadap kinerja. Pendekatan alternatif dari mutiple interaction adalah harga mutlak selisih nilai variabel independen dengan variabel kontekstual. Frocut dan Shearon (1991) misalnya, mendesain model interaksi dengan mendeviasikan (mengurangkan) skor locus of control terhadap partisipasi anggaran. Desain demikian dikarenakan sifat dari hubungan antar dimensi (variabel) yang ada. Dinyatakan oleh Frocut dan Shearon (1991) bahwa tingginya locus of control berasosiasi dengan rendahnya partisipasi dalam anggaran, dan hal ini berdampak pada meningkatnya kinerja. Model yang demikian dinyatakan oleh Venkatraman (2003) sebagai fit as matching (fit sebagai penandingan) dan bukanya fit as interaction (fit sebagai interaksi).

\section{Uji hipotesis 2}

Alternatif lain dari pendekatan interaksi dalam desain fit adalah residual analysis (Duncan dan Moores, 1989; Dewar dan Werbel, 1979, Mak, 1989). Pendekatan ini mengaplikasikan unfit dari nilai mutlak residual hasil regresi tahap pertama antara variabel sistem kontrol terhadap PEU. Nilai unfit tersebut kemudian diregresikan secara simultan terhadap kinerja sebagai variabel outcome (persamaan (8) dan (9)).

Hasil penelitian ini menunjukkan bahwa deviasi fit dari OCS, MCS dan SP terhadap PEU tidak berpengaruh terhadap kinerja perusahaan. Hasil pengujian hipotesis kedua ini disajikan dalam tabel 5 (Lampiran 2).

Mengacu pada tabel 5, nilai VIF dari masing-masing $\varepsilon$ menunjukkan nilai sekitar 1 (jauh dibawah 10) yang berarti tidak ada multikolinieritas dalam persamaan. Demikian juga untuk deteksi heteroskedastisitas dengan uji Glejser (Lampiran 3) 
menunjukkan bahwa nilai p-value dari regresi $\mid$ ci $\mid$ terhadap $\left|\varepsilon^{\prime}\right|$ tidak ada yang signifikan, yang berarti model homoskedastis. Berdasarkan pada fakta ini, model yang dihasilkan merupakan model yang terbaik meskipun menunjukkan penolakan terhadap hipotesis yang diajukan. Disisi lain, meskipun deviasi antara PEU-SP (|\&3|) menunjukkan nilai p-value yang signifikan pada level 0.1, namun sign (tanda) dari variabel tersebut tidak sesuai dengan ekpektasi dalam hipotesis. Duncan dan Moores (1989), Dewar dan Werbel (1979), Mak (1989), Drazin dan Van de Ven (1985), menunjukkan bahwa nilai residual merupakan unfit dari hubungan variabel kontekstual dan organisasional. Hal ini mengindikasikan bahwa korelasi antara unfit dengan kinerja dibentuk melalui hubungan yang negatif dalam perspektif kontinjensi.

Hasil riset ini konsisten dengan hasil penelitian Mak (1989) yang menyimpulkan bahwa dengan pendekatan residual analysis, PEU tidak memoderasi pengaruh OCS, MCS, dan SP terhadap kinerja keuangan. Namun hasil riset ini tidak konsisten dengan hasil temuan Duncan dan Moores (1989) dan Dewar dan Werbel (1979).

\section{Uji hipotesis 3}

Uji hipotesis 3 dalam penelitian ini dilakukan melalui tiga tahap. Pertama, penentuan skor ideal dari variabel-variabel dalam dimensi organisasional-kontekstual yang hendak diuji dalam penelitian. Kedua, dengan mengaplikasikan persamaan (10) dan skor ideal untuk dimensi PEU, OCS, MCS dan SP (masing-masing 70, 35, 49 dan 49) dapat dihitung nilai distance perusahaan tertentu Nilai skor ideal untuk masingmasing variabel ditentukan berdasarkan nilai tertinggi yang mungkin dicapai untuk setiap kombinasi variabel-variabel dalam masing-masing dimensi (Bambang Riyanto, 2001). Dengan demikian, untuk PEU dengan jumlah item 10 dan skala maksimal 7, memiliki nilai ideal 70. Berdasar nilai distance yang diperoleh, tahap terakhir adalah mengkorelasikan (atau meregresikan) skor distance tersebut dengan kinerja (ROA).

Hasil pengujian secara lengkap disajikan dalam Lampiran 3 dan diringkas dalam tabel 6. Berdasarkan pada tabel 6, dapat diketahui bahwa nilai $\beta$ untuk Distance Seluruh Variabel signifikan pada p-value $0.023(<0.05)$, dengan sign negatif. Hal ini menunjukkan bahwa distance antara PEU-OCS-MCS-SP berpengaruh terhadap kinerja (ROA). Secara spesifik dapat dinyatakan bahwa dalam perspektif kontinjensi kinerja dipengaruhi oleh interaksi PEU dengan variabel-variabel organisasional: OCS, MCS dan SP. Lebih jauh, hasil penelitian ini mendukung kesimpulan Drazin dan Van de Ven (1985) dan investigasi dari Bambang Riyanto (2001). Sebagai tambahan, hasil pengujian heteroskedastisitas menunjukkan bahwa model ini homoskedastis (Apendix C).

Selanjutnya, uji regresi sederhana antara masing-masing ditance PEU-OCS, PEU-MCS dan PEU-SP dengan kinerja (ROA) menujukkan hasil yang signifikan untuk semua variabel pada level 0.05 . Hasil selengkapnya dapat dilihat pada lampiran 3 , yang diringkas pada table 7 . 
Dari hasil-hasil penelitian terlihat bahwa pendekatan sistem lebih menggambarkan realita hubungan antar dimensi. Hal ini dikarenakan bahwa dalam perspektif empirik, hubungan antara berbagai variabel dalam dimensi organisasional dengan variabel-variabel dalam dimensi kontekstual bersifat sistemik dan simultan. Hubungan antar antar variabel kontekstual dan organisasional terjadi dalam space yang memungkin adanya kombinasi antar variabel secara lebih sistemik dan terstruktur membentuk pola yang berimplikasi terhadap kinerja organisasi.

\section{KESIMPULAN DAN KETERBATASAN PENELITIAN}

Berdasarkan pada pembahasan yang telah dikemukakan sebelumnya, hasil penelitian ini secara khusus dapat disimpulkan sebagai berikut:

Dalam perspektif pendekatan sistem, ketidakpastian lingkungan yang dipersepsikan (PEU) dan sistem kontrol akuntansi, dalam hal ini Operational Control System, Management Control System dan Strategic Planning, berpengaruh terhadap kinerja perusahaan (ROA)

Hubungan antara berbagai variabel dalam dimensi kontekstual-organisasional dapat dijelaskan dengan teori kontinjensi dengan menggunakan pendekatan fit melalui multiple interaction, residual analysis dan system. Dalam hal ini, pendekatan system diakui lebih baik dalam menguji hubungan antar dimensi kontekstual-organisasional tersebut.

Secara spesifik, penelitian ini tidak mampu menolak hipotesis 3. Meskipun demikian, kegagalan pembuktian hipotesis 1 dan 2 bukan berarti kegagalan teori kotinjensi dalam menjelaskan fenomena hubungan variabel organisasional-kontekstual, namun lebih disebabkan oleh faktor kelemahan pendekatan uji teori kontinjensi yang digunakan (multiple interaction dan resydual analysis).

Penelitian ini memiliki keterbatasan dalam pengukuran kinerja sampel perusahaan. Hal ini karena penelitian ini mengaplikasi data empirik dari kalangan industri perbankan (BPR) yang secara umum ukuran kinerjanya ditentukan berdasarkan CAMEL, dan bukan ROA. Disisi lain, studi secara lebih mendalam dapat dilakukan untuk sampel indutri manufaktur yang memiliki kompleksitas sistem kontrol yang lebih tinggi.

\section{$\underline{\text { References: }}$}

Anthony. RN dan Vijay Govindarajan (1998) Management Control Systems, Ninth Edition, Mc. Graw-Hill.

Bambang Riyanto LS., (2001) Alternative approach to examining a contingency model in accounting research: a comparison, Jurnal Bisnis dan Akuntansi, vol. 1 No. 1, Februari, pp. 12-32. 
Bank Indonesia, (1999) Informasi peraturan dibidang perbankan, September, BISemarang.

, (2000) Statistik ekonomi-keuangan daerah propinsi Jawa Tengah, Oktober, BI-Semarang.

, (1999) Daftar alamat BPR dan BPR-BKK, BI-Makassar Bays, Marianne, (2000) Organizing for information systems quality: a structural contingency theory investigation, http://panoptic.csustan.edu/cpa96/pdf.

Boulton, WR., et al., (1982) Strategic Planning: determining the impact of environmental Characteristics and Uncertainty, Academy of Management Journal, 25, pp. 500-519.

Burns, W.J., Jr., and J.H. Waterhouse (1975) Budgetary control and organizational structure, Journal of Accounting Research, pp.307-321.

Chenhall, R.H., (2003) Management control system design within its organizational context: Findings from contingency-based research and directions for the future, Accounting, Oreganizations and Society, 28 (2-3), pp. 127-168.

and D. Morris, (1986) The impact of structure, environtment, and interdependence on the perceived usefulness of management accounting systems, the Accounting Review, January, pp. 16-35.

Chong, Vinchent K., (1996) Management Accounting System (MAS), Task Uncertainty and Managerial Performance: A Research Note, Accouting organizations and society, Vol. 21, No. 5 PP.115-121.

, Ian R. C. Eggleton, Michele Leong, (2001) "The impact of market competition and budgetary participation on performance and job satisfaction: Evidence from the Australian banking and financial services sectors, Working Paper, January, Department of Accounting and Finance, Faculty of Economics and Commerce, The University of Western Australia, Western Australia.

and Chong KM, (2004) An Examination of the Effects of the otivational and Informational Roles of Budget Participation on Performance, working paper, 
Department of Accounting and Finance, Faculty of Economics and Commerce, The University of Western Australia.

Dewar, Robert, and James Werbel, (1979) Universalistic and contingency predictions of employee staisfaction and conflict, Adminstrative Science Quartelrly, September, Vol. 24.

Drazin, R and AH Van De Ven (1985) Alternative Forms nof Fit in Contingency Theory, Administrative science quartely, 30, pp. 514-538. Duncan, Keith, and Ken Moores (1989) Residual analysis: a better methodology for contingency studies in management accounting, Journal of Management Accounting Research, Vol 1, Fall.

Frucot, V., W.T. Shearon, (1991) Budgetory participation, locus of control, and Mexican managerial performance and job stisfaction, The Accounting Review, vol. 66. No. 1, pp. 80-99.

Ghozali, Imam (2002) Aplikasi multivariate dengan program SPSS, Badan Penerbit Universitas Diponegoro, Semarang.

Gordon, L.A., and D. Miller, (1976) A contingnecy framework for the design of accounting information systems, Accounting, Organizations and Society, pp. 59-69.

, and V.K. Narayanan (1984) Management accounting systems, Perceived environtmental and organizations structure: an empirical investigation, Accounting, Organizations and Society, pp. 34-47.

Gregson, Terry, et al., (1994) Role ambiguity, role conflict, and perceived environtmental: are the scale masruring separate construct for accountant, Behavioral Research in Accounting, Vol. 6., pp. 144-159.

Gudono, M., (1999) Teori akuntansi keperilakuan, Semiloka sehari: Metodologi Penelitian Akuntansi Keperilakuan, Novotel, Yohyakarta.

Gul, F.A., (1991), The effect of management accounting systems and environtmental uncertainty onsmall business manger's performance, Accounting and Buisness research, pp.57-61. 
, and Yew Ming Chia, (1994) Thee effect of management accounting systems, perceived environtmental uncertainty and decentralization on managerial perforamnce: a test of three-way interaction, Accounting Organizations and Society, vol. 19, pp. 413-426.

Hartmann, Frank GH., and Frank Moers (1999) Testing contingency hypotheses in budgetary research: an evaluation of the use of moderated regression analysis, Accounting, Organization dan Society, Vol. 24 pp. 291-315

Hayes, D.C., (1977), pp.22-39. The contingency theory of managerial accounting, The Accounting Review, pp. 22-39.

Joko Sugiarsono, (1999) Bank-bank kecil dan menengah, SWA, No. 22/XV/4-17, November.

Kennis, (1979) Effects of Budgetary goal characteristics on managements attitudes and Performances. The Accounting Review, 54, 707-721.

Mak, Yuen Ten, (1989) Contingency Fit, Internal Consistency and Financial Performance, Journal of Business Finance \& Accounting, 16(2), Spring.

Merchant, K., (1981) The design of corporate budgeting systems: influences on managerial behavior and performance, The Accounting Review, 56, 813, 829

Milliken, F. J. (1990) Perceiving and interpreting environmental change: An examination of college administrators' interpretation of changing demographics, Academy of Management Journal, 33, pp. 42-63.

Muhammad Ja'far S., (2001) Pengaruh sistem kontrol terhadap kinerja keuangan: uji fit versus uji internal consistency, Tesis, Unpublished, Universitas Diponegoro.

Muhammad Syafruddin, (2000) Pengaruh moderasi lingkungan pada sistim kontrol akuntansi dan kinerja perusahaan, Seminar Nasional Akuntansi 3, IAI, Kompartemen Akuntan Pendidik, Unpublished.

NIST (National Institute of Standards and Technology), (2004) Euclidean distance, Balck, E. Paul (ed.):paul.black@ nist.gov, http://www. Nist.gov./dads/HTML/euclidndstnc.html 
Otley, David T., (1980) The Contingency Theory of management Accounting Achievement and prognosis, Accounting Organizations and Society, 5, p. 413-428.

Piper, J., (1977) Determinants of financial control systems for multiple retailers, Paper, unpublished, University of Lourghborough.

Shield, Michael D and F Johnny Deng, Yutaka Kato, (2000) The Design and Effect of Control Systems: Test of direct and indirect-effect Models, Accounting Organization and Society, 25, 185-202.

Simons, Robert, (1987) Accounting Controls Systems and Business Strategy: An empirical Analysis, Accounting Organizations and society, Vol. 12, 4, PP. 357-374

Veliyath, Raj, et al., (1997)Organizational control systems: matching controls with organizational levels, Review of Business, Winter, pp. 20-24

Venkatraman, N., (1989) The concept of fit in strategy reserach: toward verbal and statistical corespondence, The Academy of Management Review, Vol. 14, No. 3, pp. 423-444

Waterhouse, J.H., and P. Tiesen, (1978) A contingency framework for management accounting systems research, Accounting, Organizations and Society, pp. 6576 
